\title{
PENGARUH PENGGUNAAN MEDIA PEMBELAJARAN DENGAN SOFTWARE PREZI TERHADAP MINAT BELAJAR MATEMATIKA SISWA
}

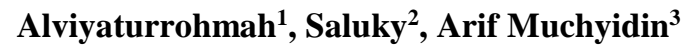 \\ Tadris Matematika \\ Institut Agama Islam Negeri (IAIN) Syekh Nurjati Cirebon \\ E-mail: Alviya.vhie@gmail.com ${ }^{1)}$,luke4line@gmail.com ${ }^{2)}$,wak_badjra@yahoo.com ${ }^{3)}$
}

\begin{abstract}
The use of media in learning activity can be a solution for teachers to overcome the problems that arise in learning. One of the problem is learning interest. It is important for teachers to cultivate students' learning interests. One of the media that can be used in learning is learning media with prezi software. Learning media with prezi sofwtare can be inserted with images, videos, music that can stimulate students' interest in learning. Population in this research is all class VIII SMP Negeri 4 Palimanan Kabupaten Cirebon while sampling using cluster random sampling technique and elected class VIII E as experiment class.Based on the results of the data obtained; the results of questionnaire analysis of students' responses to learning mathematics using prezi software showed a strong criteria with an average of $71 \%$ and the results of student interest in mathematics questionnaire analysis also showed a strong criteria with an average of $80 \%$. Based on the results of the hypothesis, it can be seen that the value of $t_{\text {hitung }}>t_{\text {-tabel, }}$ that is 4.546>1.7011. Because $t_{\text {_hitung }}>t_{-t a b e l}$, then the decision to be taken is to reject $H_{0}$ and accept $H_{a}$, it means that the hypothesis is accepted. The writer take conclusion that there is a significant influence between learning media with prezi software to the students' learning interest in mathematics.
\end{abstract}

Key words: Learning media, prezi software, learning interest

\section{PENDAHULUAN}

Saat ini penggunaan teknologi berkembang sangat pesat, contohnya yaitu penggunaan teknologi internet. Pernyataan ini didukung oleh data Asosiasi Penyelenggara Jasa Internet Indonesia (APJII), pengguna internet di Indonesia terus mengalami peningkatan. Tahun 1998 hanya 500 ribu orang yang menggunakan internet, namun dimulai pada tahun 2012 pengguna internet meroket menjadi 63 juta orang. Angka itu terus meroket sampai pada tahun 2016, pengguna internet mencapai 132,7 juta (APJII, 2016).

Berbicara mengenai teknologi, tentu tak jauh dari pembicaraan mengenai ilmu pengetahuan atau pendidikan. Karena ilmu pengetahuan dan teknologi seharusnya berkembang secara bersamaan. Jika teknologi berkembang tanpa pendidikan, maka akan terjadi kesalahan dalam penggunaanya begitupun jika Pendidikan tanpa teknologi, pendidikan akan tertinggal dan tidak akan mencapai tujuan yang maksimal.Pendidikan disini difokuskan kepada pembelajaran yang terjadi di Sekolah. Sedangkan, pembelajaran yang ada di sekolah saat ini kebanyakan bersifat monoton. Kadang- kadang guru ingin memilih beban seminimal mungkin dalam pelaksanaan tugas mengajar, ini terbukti penggunaan metode ceramah paling populer di kalangan guru (Sudarwan, 2013).

Dalam konteks yang lebih spesifik, dapat dikatakan bahwa kebijakan penyelenggaraan pendidikan, baik yang diselenggarakan oleh pemerintah, pemerintah daerah, maupun masyarakat harus mampu memberikan akses pemahaman dan penguasaan teknologi mutakhir yang luas kepada para peserta didik (Deni, 2011). Dalam rangka kegiatan pendidikan, ada beberapa media yang dapat digunakan, mulai dari yang paling sederhana sampai kepada yang canggih. Beberapa media teknologi pendidikan dimaksud antara lain : Papan tulis, Bulletin board dan display, Gambar dan ilustrasi fotografi, Slide dan filmstrip, Fim, Rekaman Pendidikan dan masih banyak lagi (Sudarwan, 2013).

Penggunaan media pembelajaran dapat menarik perhatian siswa, karena pembelajaran yang dilakukan berbeda dengan biasanya. Sejalan dengan yang disampaikan Sadirman (Sadirman, 2012), bahwa media pembelajaran adalah segala 
sesuatu yang dapat digunakan untuk menyalurkan pesan dari pengirim ke penerima sehingga dapat merangsang pikiran, perasaan, minat, dan perhatian siswa sedemikian rupa sehingga proses belajar terjadi.

Salah satu media yang dapat digunakan dalam pembelajaran yaitu media pembelajaran dengan software prezi. Software prezi masih jarang digunakan oleh para pendidik, padahal pembuatannya tidak terlalu rumit, tetapi hasil yang didapat sangat bagus dan menarik bagi para peserta didik. Software Prezi merupakan semacam program multimedia yang memungkinkan pengguna untuk memasukkan video, audio, teks dan gambar. Selain itu, pengguna dapat mendownload slide power point, mendownload gambar dan menggunakan link YouTube (Wafaa, 2015).

Kelebihan dari software Prezi ini adalah adanya Zooming User Interface (ZUI), yang memungkinkan pengguna Prezi untuk memperbesar dan memperkecil tampilan media presentasi pengguna. Penggunaan software prezi bisa melatih kemampuan Pendidik dalam berfikir kreatif dan inovatif, juga bisa membuat siswa memiliki pengalaman baru dalam belajar dan membuatnya mengenal penggunaan teknologi dalam pembelajaran.

Penggunaan software prezi dalam pembelajaran juga bisa menumbuhkan minat siswa ketika belajar. Dalam penggunaannya, bisa disisipi dengan gambar, video, musik yang dapat merangsang minat belajar siswa. Disadari atau tidak, minat menjadi faktor penting yang dapat mempengaruhi hasil belajar. Oleh karenanya, penting bagi para pendidik dalam menumbuhkan minat beajar siswa. Seperti yang disampaikan oleh Djaali (Djaali, 2013) bahwa Minat tidak dibawa sejak lahir, melainkan diperoleh kemudian.

Apalagi dalam pembelajaran matematika, sangat dibutuhkan sekali adanya minat dalam belajar, karena matematika menjadi salah satu pelajaran yang wajib di kuasai para peserta didik. Oleh karena itu, penting bagi guru membangkitkan minat siswa dalam mengikuti pembelajaran matematika.
Karena siswa yang berminat cenderung akan semangat dalam mengikuti pembelajaran dan akan berpengaruh positif juga terhadap hasil belajar matematikanya, begitupun sebaliknya.

Berdasarkan permasalahan yang telah diungkap di atas, Penulis tertarik untuk melakukan penelitian dengan judul
Pengaruh
Penggunaan
Media Pembelajaran dengan Software Prezi terhadap Minat Belajar Matematika Siswa.

\section{LANDASAN TEORI}

\section{Media Pembelajaran dengan Software Prezi}

Kata media berasal dari bahasa Latin medius yang secara harfiah berarti 'tengah', 'perantara' atau 'pengantar'. Dalam bahasa Arab, media adalah perantara atau pengantar pesan dari pengirim kepada penerima pesan (Arsyad, 2013). Media dalam proses belajar mengajar cenderung diartikan sebagai alat-alat grafis, photografis, atau elektronis untuk menangkap, memproses, dan menyusun kembali informasi visual atau verbal (Arsyad, 2013). Apabila media itu membawa pesan-pesan atau infromasi yang bertujuan instruksional atau mengandung maksud-maksud pengajaran maka media itu disebut media pembelajaran (Arsyad, 2013).

Maka dapat ditarik kesimpulan bahwa media pembelajaran adalah alat atau perantara yang dapat digunakan guru untuk menyampaikan pesan/ pengajaran kepada siswa ynga disertai dengan gambar, suara, atau objek nyata lainnya yang dapat merangsang siswa untuk belajar dan dapat menumbuhkan ketertarikan/minat siswa ketika belajar.

Selain itu media juga memiliki fungsi dalam pembelajaran. Fungsi utama media pembelajaran adalah sebagai alat bantu mengajar yang turut mempengaruhi iklim, kondisi, dan lingkungan belajar yang ditata dan diciptakan oleh guru (Hamalik, 2013). Dengan kata lain, media pembelajaran berfungsi untuk mempermudah siswa dalam menerima pembelajaran dari guru karena penyampaiannya disertai dengan gambar atau suara yang mampu merangsang stimulus siswa dalam belajar. 
Prezi adalah alat presentasi berbasis web yang inovatif yang di tempatkan di atas kanvas yang tak terbatas. Kanvas dan fitur zoom-nya adalah kelebihan dari Prezi. Zooming out (perkecil) menyediakan gambaran dan zooming in (perbesar) memberikan rincian. Pengguna dapat melihat presentasi Prezi sebagai mind map yang berukuran besar. Penggunaanya yaitu menempatkan teks, gambar, dan video di atas kanvas dan struktur konten dengan frame. Membuat sebuah poin penting dengan ukuran besar dan membuat rinciannya dengan ukuran yang lebih kecil. Garis edar pada Prezi menetapkan alur cerita dari presentasi (Groenendaal, 2014).

Menurut Saputra (Saputra, 2011) The Zooming Presentation Prezi Zoom in dan Zoom out dengan tampilan map books dapat mengubah segalanya dalam hal membuat dan menampilkan sebuah ide ataupun gagasan pada sebuah tampilan dan dapat melihat keterkaitan dalam sebuah tampilan slide dengan slide lainnya dengan mudah, dinamis, dan dengan transisi yang sangat halus tanpa harus kehilangan arah. Hal ini sangat membantu dalam pembelajaran dan mempermudah peserta didik memahami materi yang sedang ditampilkan.

Prezi juga mempunyai beberapa kelebihan, di antaranya, seperti yang disampaikan Tarr dalam (Embi, 2011) bahwa multimedia Prezi mempunyai kelebihan yaitu (1) mempunyai faktor lebih daripada slide lain, (2) tidak perlu berpindah dari satu slide ke slide lain. Cukup dengan satu kanvas besar yang bisa disisipi gambar, video, data, dan lain-lain. Jadi untuk presentasi dengan Prezi tidak perlu banyak slide cukup 1 slide saja, (3) mudah untuk menggabungkan gambar, bunyi dan video dalam satu tampilan, (4) sangat mudah digunakan.

Selain itu, prezi juga memiliki beberapa kelemahan. Diantaranya seperti yang di sampaikan oleh Brian \& Alyson (Perron \& Stearns, 2010) kelemahan program Prezi tersebut diantaranya: 1) Perbedaan fasilitas pada akun Prezi yang berlangganan dan akun yang tidak berbayar membuat pengguna akun tak berbayar menjadi terbatas pada penggunaan template. 2) Prezi merupakan program presentasi berbasis internet yang memungkinkan pengguna menyisipkan berbagai macam konten dalam berbagai macam ukuran mengharuskan pengguna memiliki akses internet yang cepat dan stabil. 3) Prezi membutuhkan perangkat keras dan perangkat lunak komputer yang mendukung. Pengguna harus memperbarui perangkat keras dan perangkat lunak yang dapat mendukung program Prezi.

\section{Minat Belajar}

Minat atau interest adalah kecenderungan dan kegairahan yang tinggi atau keinginan yang besar terhadap sesuatu (Mahmud, 2006). Minat besar sekali pengaruhnya terhadap kegiatan seseorang sebab dengan minat ia akan melakukan sesuatu yang diminatinya dengan senang hati. Sebaliknya tanpa minat, seseorang mungkin tetap melakukan kegiatannya tapi dengan terpaksa atau bahkan mungkin tidak melakukannya sama sekali. Minat juga didefinisikan sebagai kecenderungan hati yang tinggi terhadap sesuatu (Djaali, 2013). Minat dapat mempengaruhi kualitas belajar seseorang dalam bidang-bidang studi tertentu dan dari kualitas belajar juga akan berpengaruh terhadap hasil belajarnya.

Belajar adalah kegiatan yang berproses dan merupakan unsure yang sangat fundamental dalam penyelenggaraan setiap jenis dan jenjang pendidikan. Ini berarti, bahwa berhasil atau gagalnya pencapaian tujuan pendidikan itu amat bergantung pada proses belajar yang dialami siswa baik ketika ia berada di sekolah maupun di lingkungan rumah atau keluarganya sendiri (Syah, 2012). Syah (Syah, 2012) juga menambahkan bahwa belajar secara umum dapat dipahami sebagai tahapan perubahan seluruh tingkah laku individu yang relative menetap sebagai hasil pengalaman dan interaski dengan lingkungan yang melibatkan proses kognitif.

Maka dapat disimpulkan bahwa minat belajar matematika adalah ketertarikan seseorang terhadap pembelajaran matematika tanpa adanya paksaan dari luar dirinya, sehingga dapat memperoleh perubahan tingkah laku maupun pengetahuan berdasarkan hasil pengalamannya dalam pembelajaran matematika. 
Menurut Djamarah dan Syaiful Bachri (Djamarah \& Bachri, 2002) indikator minat belajar yaitu rasa suka/senang, pernyataan lebih menyukai, adanya rasa ketertarikan adanya kesadaran untuk belajar tanpa di suruh, berpartisipasi dalam aktivitas belajar, memberikan perhatian.

Menurut Slameto (Slameto, 2010) beberapa indikator minat belajar yaitu: perasaan senang, ketertarikan, penerimaan, dan keterlibatan siswa.

Indikator minat belajar yang digunakan dalam penelitian ini adalah sebagai berikut:

1. Perasaan Senang

Apabila seorang siswa
memiliki perasaan senang
terhadap pelajaran tertentu
maka tidak akan ada rasa
terpaksa untuk belajar.

2. Keterlibatan Siswa

Ketertarikan seseorang akan obyek yang mengakibatkan orang tersebut senang dan tertarik untuk melakukan atau mengerjakan kegiatan dari obyek tersebut.

3. Ketertarikan

Berhubungan dengan daya dorong siswa terhadap ketertarikan pada sesuatu benda, orang atau kegiatan.

4. Perhatian Siswa

Minat dan $\begin{array}{r}\text { perhatian } \\ \text { merupakan }\end{array}$ dua hal yang
dianggap sama ralam
penggunaan
perhatian sehari-hari,
konsentrasi siswa merupakan
pengamatan dan pengertian,
dengan mengesampingkan yang
lain. Siswa memiliki minat
pada obyek tertentu maka
dengan sendirinya akan
memperhatikan obyek tersebut.

\section{METODE PENELITIAN}

\section{Metode dan Desain Penelitian}

Penelitian ini dilaksanakan di SMP Negeri 4 Palimanan, Kecamatan Palimanan Kabupaten Cirebon. Metode penelitian yang digunakan dalam penelitian ini adalah metode penelitian ekseprimental. Eksperimen adalah observasi di bawah kondisi buatan ( artificial condition), dimana kondisi tersebut dibuat dan diatur oleh si peneliti. Desain yang digunakan dalam penelitian ini adaah One-shot case study, yaitu dengan hanya melibatkan 1 kelas sebagai kelas eksperimen yang mengalami perlakuan dalam pembelajaran, perlakuan di sini yaitu penggunaan media pembelajaran dengan software prezi. Adapun bentuk desain penelitiannya menurut Arikunto (Arikunto, 2013) adalah sebagai berikut:

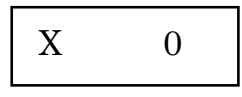

Keterangan:

$\mathrm{X}$ adalah treatment atau perlakuan.

0 adalah hasil observasi sesudah treatment.

\section{Populasi dan Sampel}

Populasi adalah keseluruhan subjek penelitian (Arikunto, 2002) .Populasi dalam penelitian ini adalah keseluruhan siswa kelas VIII SMP Negri 4 Palimanan. Menurut Arikunto (Arikunto, 2002) Sampel adalah sebagian atau wakil populasi yang diteliti. Untuk Cara pengambilan sampel pada penelitian ini adalah dengan cluster random sampling, yaitu cara pengambilan sampel dari anggota populasi dengan menggunakan acak tanpa memperhatikan strata (tingkatan) dalam anggota populasi tersebut (Sugiyono, 2016). Sehingga untuk sampel terpilih kelas VIII E yang berjumlah 30 siswa.

\section{Intsrumen Penelitian}

Instrumen penelitian yang digunakan adalah angket/kuesioner untuk kedua variable. Kuesioner, yaitu instrument penelitian dalam bentuk pertanyaan yang biasanya dimaksudkan untuk mendapatkan informasi berkaitan dengan pendapat, aspirasi, persepsi, keinginan, keyakinan, dan lain-lain secara tertulis, dan apabila pertanyaan dan jawaban dilakukan secara lisan disebut wawancara (Suharsaputra, 2012).

Angket yang digunakan dalam penelitian ini adalah model angket skala Likert. Model angket skala Likert yang digunakan dalam penelitian ini yitu berbentuk rating-scale, dimana siswa 
memberikan respon terhadap pernyataanpernyataan dengan pilihan, yaitu STS (Sangat Tidak Setuju), TS (Tidak Setuju), C (Cukup), S (Setuju), SS (SangatSetuju). Angket ini terdiri dari 20 butir pernyataan, jawaban setiap item instrument yang digunakan Skala Likert mempunyai tingkatan dari sangat positif sampai sangat negative.

\section{HASIL DAN PEMBAHASAN}

\section{Deskriptif Data}

Uji coba instrumen angket minat dilaksanakan di kelas VIII D dengan jumlah responden sebanyak 25 siswa dengan 20 butir penyataan. Pernyataan angket minat terdiri dari pernyataan positif dan negatif. Setelah dilakukan uji validitas terdapat 2 butir pernyataan yang tidak valid yaitu butir nomor 5 dan 12 sehingga butir pernyataan ini tidak digunakan dalam angket yang akan digunakan untuk penelitian.

Untuk mengukur respon siswa terhadap media pembelajaran dengan software prezi dilakukan dengan memberikan angket yang berjumlah 20 pernyataan dengan menggunakan skala Likert. Angket tersebut disebarkan kepada 30 siswa di kelas VIII E. Angket ini dibuat berdasarkan tiga dimensi aspek, yaitu: Kualitas Isi dan Tujuan, Kualitas Instruksional dan Kualitas Teknis. Adapun hasil penyebaran angket terhadap mengukur respon siswa terhadap media pembelajaran dengan software prezi siswa di kelas VIII E digambarkan pada tabel di bawah ini:

Setelah dilakukan analisis hasil angket tiap aspek dari angket respon siswa terhadap media pembelajaran dengan software prezi diketahui bahwa hasil persentase Kualitas Isi dan Tujuan sebesar $34 \%$, persentase Kualitas Instruksional sebesar $32 \%$, persentase Kualitas Teknis sebesar 34\%,. Sehingga dapat diketahui rata-rata persentase respon siswa terhadap Media Pembelajaran Dengan Software Prezi adalah sebesar $71 \%$ dengan kriteria Kuat.

Untuk mengukur minat belajar matematika siswa dilakukan dengan memberikan angket yang berjumlah 18 pernyataan yang di ukur dengan menggunakan skala Likert. Angket tersebut disebarkan kepada 30 siswa di kelas VIII E. Angket ini dibuat berdasarkan empat indikator, yaitu indikator perasaan senang, indikator keterlibatan siswa, indikator ketertarikan dan indikator perhatian. Adapun hasil penyebaran angket terhadap respon Minat Belajar Matematika Siswa di kelas VII E digambarkan pada tabel di bawah ini:

Setelah dilakukan analisis hasil angket tiap indikator dari angket minat belajar matematika siswa diketahui bahwa hasil persentase rata-rata indikator perasaan senang sebesar 74\%, Persentase rata-rata indikator keterlibatan siswa sebesar 73\%, Persentase rata-rata indikator ketertarikan sebesar $74 \%$ dan Persentase rata-rata indikator perhatian sebesar $74 \%$. Sehingga dapat diketahui rata-rata persentase Minat Belajar Matematika Siswa adalah sebesar $80 \%$ dengan kriteria Kuat.

\section{Pembahasan}

Berdasarkan hasil penelitian di SMPN 4 Palimanan, menunjukkan bahwa respon siswa terhadap media pembelajaran dengan software prezi tergolong kuat dengan rata-rata $71 \%$, sedangkan untuk minat belajar matematika siswa juga tergolong kuat dengan rata-rata $80 \%$. Hal itu didapat setelah peneliti menganalisis butir-butir pernyataan dari dua jenis angket tersebut.

Berdasarkan hasil uji hipotesis, didapat nilai $t_{\text {hitung }}$ sebesar 4,546 dan diketahui nilai $t_{\text {tabel }}$ sebesar 1,7011 dengan tingkat kepercayaan 0,05. Jika dibandingkan antara $t_{\text {hitung }}$ dengan $t_{\text {tabel }}$, dapat diketahui bahwa nilai $t_{\text {hitung }}>t_{\text {tabel }}$, yaitu 4,546 $>1,7011$. Karena $t_{\text {hitung }}>t_{\text {tabel }}$, maka keputusan yang harus diambil adalah menolak $\mathrm{H}_{0}$ dan menerima $\mathrm{H}_{\mathrm{a}}$, yang artinya terdapat pengaruh yang signifikan antara media pembelajaran dengan software prezi terhadap minat belajar matematika siswa.

Setelah diketahui bahwa terdapat pengaruh antara media pembelajaran dengan software prezi, maka langkah selanjutnya adalah mengukur seberapa besar pengaruh penggunaan media pembelajaran dengan software prezi terhadap minat belajar matematika siswa. Berdasarkan hasil perhitungan uji koefisien determinasi didapat nilai sebesar 
0,425 atau $42,5 \%$, yang artinya bahwa media pembelajaran dengan software prezi berpengaruh sebesar $42,5 \%$ terhadap minat belajar matematika siswa. Sedangkan, sisanya yaitu sebesar 57,5\% dipengaruhi oleh faktor lain.

Faktor lain yang dapat mempengaruhi minat belajar matematika siswa selain penggunaan media software prezi, yang ditemukan peneliti selam pembelajaran berlangusng diantaranya penggunaan metode pembelajaran dan kondisi ruang kelas. Ketika melakukan penelitian, peneliti menggunakan beberapa varian metode yaitu metode diskusi, metode guided note taking dan metode ceramah. Tentu respon siswa berbeda-beda pada setiap metodenya. Ada beberapa siswa yang lebih nayaman atau lebih berminat mengikuti pembelajaran ketika belajar secara berkelompok, sedangkan sebagian lainnya lebih nyaman atau lebih berminat mengikuti pembelajaran matematika ketika pembelajaran berlangsung secara individu atau menggunakan metode ceramah.

$\begin{array}{lrr} & \text { Berminat atau } & \text { tidaknya siswa } \\ \text { dalam } & \text { mengikuti } & \text { pembelajaran } \\ \text { matematika terlihat dari beberapa }\end{array}$ aktivitas yang dilakukan siswa selama pembelajaran matematika berlangsung. Siswa yang berminat akan aktif bertanya ketika ada materi yang tidak dipahami, akan menjawab setiap guru mengajukan pertanyaan dan mau maju ke depan kelas untuk mengerjakan soal yang diberikan guru. Ketika diskusi berlangsung, siswa yang berminat juga akan mengutarakan pendapatnya didepan teman-teman dan bertanya kepada temannya jika ada materi yang tidak dipahaminya.

Selain metode pembelajaran, faktor lain yang juga mempengaruhi minat belajar matematika siswa adalah kondisi kelas dan pencahayaan. Di kelas tersebut terdapat jendela yang terletak di sebelah timur sehingga cahaya langsung menembus kaca dan membuat sebagian ruang kelas menjadi silau. Oleh karenanya, ada beberapa bangku siswa yang terkena paparan cahaya dan mereka merasa terganggu dan pada akhirnya tidak nyaman ketika mengikuti pembelajaran. Pencahayaan memang diperlukan untuk menunjang pembelajaran, tapi jika cahayanya itu terlalu terang maka tidak bagus juga dalam pembelajaran.

Berdasarkan uraian dari hasil penelitian di atas, telah terbukti bahwa media pembelajaran dengan software prezi berpengaruh terhadap minat belajar matematika siswa, sehingga media pembelajaran dengan software prezi bisa menjadi salah satu media pembelajaran bagi guru untuk menumbuhkan minat belajar matematika siswa.

\section{KESIMPULAN}

Berdasarkan latar belakang dan tujuan penelitian serta hasil penelitian, maka penelitian yang berjudul "Pengaruh penggunaan media pembelajaran dengan software prezi terhadap minat belajar matematika siswa" diperoleh kesimpulan sebagai berikut :

1. Hasil angket respon siswa terhadap pembelajaran matematika yang menggunakan media pembelajaran dengan software prezi siswa secara keseluruhan memberikan reaksi positif. Hal ini dapat dilihat dari perolehan rata-rata presentase angket respon siswa terhadap media pembelajaran dengan software prezi sebesar 71\% yang menunjukkan kriteria kuat.

2. Hasil angket minat belajar matematika siswa secara keseluruhan memberikan reaksi positif. Hal ini dibuktikan dengan perolehan presentase angket minat belajar matematika siswa sebesar $80 \%$ yang menunjukkan kriteria kuat.

3. Beradasarkan hasil uji hipotesis, dapat diketahui bahwa nilai $t_{\text {hitung }}>t_{\text {tabel }}$, yaitu 4,546 $>1,7011$. Karena $t_{\text {hitung }}>t_{\text {tabel }}$, maka keputusan yang harus diambil adalah menolak $\mathrm{H}_{0}$ dan menerima $\mathrm{H}_{\mathrm{a}}$, yang artinya terdapat pengaruh yang signifikan antara media pembelajaran dengan software prezi terhadap minat belajar matematika siswa. Sedangkan, berdasarkan hasil perhitungan uji koefisien determinasi didapat nilai sebesar 0,425 atau $42,5 \%$, yang artinya bahwa media pembelajaran dengan software prezi berpengaruh sebesar 
42,5\% terhadap minat belajar matematika siswa. Sedangkan, sisanya yaitu sebesar 57,5\% dipengaruhi oleh faktor lain.

\section{SARAN}

Berdasarkan penelitian yang telah dilakukan, maka saran yang dapat diberikan peneliti adalah sebagai berikut :

1. Guru
a. Penggunaan
media
pembelajaran dengan software prezi diharapkan dapat digunakan dalam pembelajaran matematika untuk dapat menumbuhkan minat belajar matematika siswa.

b. Minat belajar merupakan sesuatu yang penting yang harus dimiliki siswa dalam mengikuti pembelajaran, oleh karenanya guru harus mampu menumbuhkan minat belajar siswa karena jika siswa tidak mempunyai minat belajar maka tidak ada ketertarikan dalam diri siswa untuk mengikuti pembelajaran.

2. Siswa

Bagi siswa, peneliti mengingatkan bahwa pentingnya minat dalam belajar karena adanya minat dapat membuat pembelajaran lebih baik dan akan berpengaruh terhadap hasil belajarnya.

3. Sekolah

Untuk sekolah diharapkan adanya suatu kebijakan yang menganjurkan guru untuk menggunakan media pembelajaran dalam menyampaiakan pembelajaran matematika agar dapat menumbuhkan minat belajar matematika siswa.

\section{DAFTAR PUSTAKA}

APJII. (2016). Penetrasi dan Perilaku Pengguna Internet Indonesia (Survey 2016), 34.

Arikunto, S. (2002). Prosedur Penelitian suatu pendekatakan praktek (Revisi V). Jakarta: PT Rineka Cipta.

Arikunto, S. (2013). Prosedur Penelitian Suatu Pendekatan Praktik. Jakarta: Rineka Cipta.

Arsyad, A. (2013). Media Pembelajaran
(Revisi 16). Jakarta: Rjawali Pers.

Deni, D. (2011). Teknologi Pembelajaran. Bandung: PT Remaja Rosdakarya.

Djaali. (2013). Psikologi Pendidikan (1st ed.). Jakarta: Bumi Aksara.

Djamarah, \& Bachri, S. (2002). Psikologi Belajar. Jakarta: Rineka Cipta.

Embi, M. (2011). Aplikasi Web 2.0 dalam Pengajaran dan Pembelajaran. Selangor: Universiti Kebangsaan Selangor.

Groenendaal, H. van. (2014). Prezi HOTSOT (Create amazing Prezi presentations through 10 exciting Prezi projects). Mumbai: Packt Publishing.

Hamalik, O. (2013). Proses Belajar Mengajar. Jakarta: Bumi Aksara.

Mahmud. (2006). Psikologi Pendidikan Mutakhir. Bandung: sahifa.

Perron, B. E., \& Stearns, A. G. (2010). A Review of a Presentation Technology: Prezi. Research on Social Work Practice. https://doi.org/10.1177/104973151039 0700

Sadirman, A. S., Rahardjo, R., Haryono, A., \& Rahardjito. (2012). Media Pendidikan : Pengertian, Pengembangan, dan Pemanfaatannya. (1st ed.). Depok: Rjawali Pers.

Saputra, I. P. W. (2011). Prezi The Zooming Prezentation. Jakarta: Elex Media.

Slameto. (2010). Belajar dan faktor-faktor yang mempengaruhinya (Revisi). Jakarta: Rineka Cipta.

Sudarwan, D. (2013). Media Komunikasi Pendidikan (1st ed.). Jakarta: Bumi Aksara.

Sugiyono. (2016). Metode Penelitian Pendidikan (Penelitian Kuantitatif, Kuaitatif dan $R \& D)$. Bandung: Alfabeta.

Suharsaputra, U. (2012). Metode Penelitian Kuantutatif, Kualitatif, dan Tindakan. Bandung: PT Refika Aditama.

Syah, M. (2012). Psikologi Belajar (Revisi 12). Jakarta: Rjawali Pers.

Wafaa, M. ali A. jehani. (2015). Using PREZI Presentation Software to Enhance Vocabulary Learning of EFL Secondary School Students. Educational Research International, 4(August), 67-81. https://doi.org/23073721 
